\title{
PENGARUH UKURAN DEWAN KOMISARIS, GENDER DIVERSITY PADA DEWAN, DAN KUALITAS AUDITOR EKSTERNAL TERHADAP AGRESIVITAS PAJAK (Studi pada Perusahaan Sektor Property dan Real Estate yang Terdaftar di Bursa Efek Indonesia tahun 2013-2017)
}

\author{
Desi Ambarsari ${ }^{1}$, Dudi Pratomo ${ }^{2}$, Kurnia $^{3}$ \\ Universitas Telkom ${ }^{1,2,3}$ \\ desiambarsari123@gmail.com
}

\begin{abstract}
This study aims to analyze the effect board of commissioner size, gender diversity in boards, and external auditor quality to tax aggressiveness. Population were property and real estate sector companies listed in Indonesia Stock Exchange (IDX) in the period of 2013-2017. The analytical method used is descriptive statistical test and panel data regression analysis using eviews. The technique of selecting the sample used is purposive sampling and obtained 28 property and real estate companies in 2013-2017 so obtained 140 units sample. The results of this study shown that simultaneously the board of commissioners size, gender diversity on the board, and the quality of external auditors influence tax aggressiveness. Partially gender diversity on the board has a negative effect on tax aggressiveness, while board of commissioners size and external auditor quality have no effect.
\end{abstract}

Keywords: Tax Aggressiveness, Board of Commissioner Size, Gender Diversity in Boards, External Auditor Quality

\begin{abstract}
ABSTRAK
Penelitian ini bertujuan untuk menganalisis pengaruh ukuran dewan komisaris, gender diversity pada dewan, dan kualitas auditor eksternal terhadap agresifitas pajak. Populasi penelitian ini adalah perusahaan property dan real estate yang terdaftar di Bursa Efek Indonesia (BEI) periode 2013-2017. Metode analisis yang digunakan adalah pengujian statistik deskriptif dan analisis regresi data panel dengan menggunakan eviews. Teknik pemilihan sampel yang digunakan yaitu purposive sampling dan diperoleh 28 perusahaan property dan real estate dengan periode penelitian selama lima tahun yaitu tahun 20132017 sehingga didapat 140 unit sampel dalam penelitian ini. Hasil penelitian ini menunjukkan bahwa bahwa secara simultan ukuran dewan komisaris, gender diversity pada dewan, dan kualitas auditor eksternal berpengaruh terhadap agesivitas pajak. Secara parsial gender diversity pada dewan berpengaruh negatif terhadap agresivitas pajak, sedangkan ukuran dewan komisaris dan kualitas auditor eksternal tidak berpengaruh.

Kata kunci: Agresivitas Pajak, Ukuran Dewan Komisaris, Gender Diversity pada Dewan, Kualitas Auditor Eksternal
\end{abstract}

\section{PENDAHULUAN}

Pajak merupakan sumber utama dalam pendapatan dalam suatu negara. Di berbagai negara, pendapatan pajak sangat penting digunakan untuk kegiatan pembangunan nasional dan sumber dana untuk kesejahteraan masyarakat. Pajak 
merupakan salah satu sumber pendapatan negara yang berasal dari rakyat. Dengan adanya pembayaran pajak maka pemerintah dapat melakukan program-program pembangunan yang dapat dinikmati rakyat. Kebanyakan wajib pajak badan (perseroan) masih mengidentikkan kewajiban membayar pajak sebagai suatu biaya karena secara finansial, pajak merupakan pemindahan sumber daya dari sektor bisnis atau dunia usaha kepada sektor publik atau pemerintah yang mengakibatkan berkurangnya daya beli wajib pajak (Santoso dan Rahayu, 2013).

Berdasarkan Undang-Undang No.16 Tahun 2009, pajak merupakan kontribusi wajib kepada negara yang terutang oleh orang pribadi atau badan yang bersifat memaksa berdasarkan undang-undang, dengan tidak mendapatkan imbalan secara langsung dan digunakan untuk keperluan negara bagi sebesarbesarnya kemakmuran rakyat. Pajak adalah iuran rakyat kepada kas negara berdasarkan undang-undang yang bersifat memaksa yang langsung dapat ditunjukkan dan digunakan untuk membayar pengeluaran umum. Disisi lain masyarakat dapat dikatakan sebagai pihak yang diberi perlindungan memiliki kewajiban untuk ikut serta dalam menjalankan fungsinya yang bisa ditunjukkan melalui keikutsertaannya dalam pembiayaan negara. Maka, pemungutan pajak dari rakyat dilakukan sebagai salah satu sumber modal atau dana untuk dapat mewujudkan kesejahteraan seluruh masyarakat. Rakyat yang ikut serta membayar pajak dapat dikatakan sebagai wajib pajak.

Agresivitas pajak merupakan suatu tindakan untuk mengurangi penghasilan kena pajaknya melalui perencanaan pajaknya baik secara legal (tax avoidance) maupun illegal (tax evasion) guna mengecilkan beban pajaknya. Bagi perusahaan dengan beban pajak yang tinggi akan mengurangi keuntungan perusahaannya. Tindakan pajak agresif tidak selalu berawal dari ketidakpatuhan akan peraturan perpajakan, tapi juga dari penghematan pajak yang dilakukan sesuai dengan peraturan. Semakin perusahaan memanfaatkan celah peraturan untuk menghemat beban pajak maka perusahaan dianggap telah melakukan pajak agresif meskipun tindakan tersebut tidak menyalahi peraturan yang ada (Kamila, 2014).

Dalam RAPBN 2014 dijelaskan bahwa pajak digunakan sebagai sumber daya bagi pemerintah untuk mendanai berbagai macam kepentingan masyarakat seperti peningkatan pendidikan dan kesejahteraan rakyat, pembangunan infrastruktur umum, mendukung pertahanan dan keamanan, serta untuk pembangunan di daerah. Pajak pada sektor property dan real estate dapat diandalkan sebagai penerimaan pajak bagi negara. Hal tersebut dikarenakan dalam usaha property dan real estate terdapat banyak aspek pajak seperti, PPh, PPN, Pajak Pertambahan Nilai dan Pajak Penjualan atas Barang Mewah (PPnBM), PBB, Bea Perolehan Hak atas Tanah dan Bangunan dan PPh Final (Wahyudi, 2012).

Bisnis property mengindikasikan adanya potensi penerimaan pajak yang menjanjikan namun dapat diketahui bahwa banyak terjadi penghindaran pajak yang dilakukan oleh perusahaan-perusahaan property yang membuat negara kehilangan potensi penerimaan triliunan rupiah. Investasi tanah dan bangunan, atau dikenal dengan istilah property masih menjadi salah satu investasi favorit masyarakat Indonesia karena investasi ini relatif aman dan memberikan imbalan hasil yang baik. Menyadari adanya potensi penerimaan pajak tersebut, Direktorat

\section{3}

Ambarsari $^{1}$, Pratomo $^{2}$, Kurnia ${ }^{3}$ 
Jendral Pajak (DJP) menetapkan sektor property dan real estate sebagai salah satu sektor prioritas penggalian potensi pajak di tahun 2013 dan masih berlanjut hingga saat ini. DJP memperkirakan masih banyak terjadi penghindaran pajak, khususnya Pajak Penghasilan (PPh), yang dilakukan oleh perusahaan-perusahaan property dan real estate di Indonesia. Di Indonesia kasus pada Real Estate Indonesia (REI) yang dituduh oleh Direktorat Jenderal Pajak (DJP) terkait dokumen transaksi pembayaran pajak yang diperkirakan banyak melakukan penghindaran pembayaran Pajak Penghasilan (https://majalahpajak.net/).

Potensi penerimaan pajak dari sektor properti berasal dari Pajak Penghasilan $(\mathrm{PPh})$ Final Pasal 4 ayat (2) final yaitu penghasilan yang diterima oleh penjual karena telah melakukan transaksi jual beli tanah/bangunan sebesar 5\% dan Pajak Pertambahan Nilai (PPN) atas transaksi barang kena pajak berupa tanah/bangunan yang bukan kategori rumah sangat sederhana sebesar 10\%. Sedangkan pajak yang dipungut oleh pemerintah daerah dalam transaksi properti adalah Bea Perolehan Hak Atas Tanah dan Bangunan (BPHTB) sebesar 5\%. Penelitian awal Ditjen Pajak, menemukan adanya potential loss penerimaan pajak akibat tidak dilaporkan transaksi sebenarnya jual-beli tanah/bangunan termasuk properti, real estate dan apartemen. Hal ini terjadi karena pajak yang dibayarkan menggunakan transaksi berbasis Nilai Jual Objek Pajak (NJOP) bukan berbasis transaksi sebenarnya atau riil (https://finance.detik.com/properti/).

Fakor-faktor yang berkaitan dengan agresivitas pajak antara lain adalah ukuran dewan komisaris, gender diversity pada dewan, dan kualitas auditor eksternal. Ukuran dewan komisaris merupakan jumlah anggota dewan komisaris yang berasal dari internal ataupun eksternal perusahaan (Asmoro, 2016). Dewan komisaris mempunyai tugas melakukan pengawasan terhadap kebijakan direksi dalam menjalankan perusahaan dan memberikan pengarahan atau nasihat kepada direksi dalam menjalankan kegiatan perusahaan. Dewan komisaris dalam suatu perusahaan lebih ditekankan pada fungsi monitoring dari implikasi kebijakan direksi. Dewan komisaris memegang peranan penting dalam mengarahkan strategi dan mengawasi jalannya perusahaan serta memastikan bahwa para manajer benarbenar meningkatkan kinerja perusahaan sebagai bagian dari tujuan perusahaan. Dalam penelitian yang dilakukan oleh Richardson dan Lanis (2011), menemukan bahwa ukuran dewan komisaris memiliki pengaruh yang signifikan terhadap agresivitas pajak perusahaan. Sebaliknya, Aliani dan Ali (2012) menemukan adanya non-signifikansi antara ukuran dewan komisaris dan agresivitas pajak. Selain itu dalam penelitian yang dilakukan oleh Wulandari dan Septiari (2015) menemukan bahwa ukuran dewan komisaris memiliki pengaruh negatif dan signifikan terhadap effective tax rate.

Faktor kedua yang dianggap mempengaruhi tindakan agresivitas pajak yaitu gender diversity pada dewan perusahaan. Menurut Arfken dkk (2004) keberagaman gender (gender diversity) dalam suatu perusahaan dapat memberikan manfaat dalam menambah pengetahuan, penemuan ide-ide baru, dan wawasan untuk membantu memecahkan masalah, meningkatkan perencanaan strategis, pengetahuan baru atau pendapat dan pengalaman. Menurut Boussaidi dan Mounira (2015) keberagaman gender (gender diversity) dapat diukur dengan menggunakan jumlah adanya perempuan dalam dewan. Khoula dan Ali (2012)

\section{4}

Ambarsari $^{1}$, Pratomo $^{2}$, Kurnia $^{3}$ 
menyatakan bahwa keberagaman gender tidak berpengaruh pada tax effective rate karena presentase perempuan dalam dewan yang lebih rendah daripada persentase laki-laki. Boussaidi dan Mounira (2015) menyatakan bahwa keberagaman gender berpengaruh positif dan signifikan terhadap agresivitas pajak perusahaan. Sedangkan Aliani dkk (2011) menunjukkan bahwa keberagaman gender pada dewan berpengaruh negatif terhadap optimalisasi pajak.

Faktor lainnya yang menyebabkan adanya tindakan agresivitas pajak adalah kualitas auditor eksternal. Manajemen memiliki tanggung jawab dalam memberikan informasi kepada stakeholders mengenai keseluruhan aktivitas perusahaan termasuk dalam pelaporan keuangan. Perusahaan dituntut untuk memberikan laporan keuangan yang kredibel meskipun berbagai macam fleksibilitas dalam standar akuntansi dapat memberi kemungkinan kepada manajer untuk mengambil keuntungan tersendiri dan memberikan informasi yang salah. Penghindaran pajak yang termasuk dalam bentuk manajemen pajak tersebut sangat berkaitan dengan penyajian laporan keuangan yang telah diverifikasi oleh auditor eksternal sebelum dipublikasikan. Richardson dkk (2013) menemukan bahwa, perusahaan yang menggunakan auditor eksternal Big Four dan non Big Four. Ia menyimpulkan bahwa penggunaan auditor Big Four dapat mengurangi agresivitas pajak. Boussaidi dan Mounira (2015) menyimpulkan bahwa kualitas auditor eksternal Big Four tidak berpengaruh negatif terhadap agresivitas pajak. Sedangkan Dewi dan Jati (2014) serta Maharani dan Suardana (2014) menemukan bahwa kualitas audit berpengaruh negatif terhadap tax avoidance. Selain itu Kusuma dan Firmansyah (2018) menyatakan bahwa kualitas auditor eksternal Big Four tidak berpengaruh terhadap agresivitas pajak.

\section{TINJAUAN PUSTAKA DAN PENGEMBANGAN HIPOTESIS Agresivitas Pajak}

Pajak merupakan hal yang tidak bisa dipisahkan dari operasional perusahaan dalam suatu negara. Dalam usahanya mengurangi beban pajak, perusahaan akan melakukan perencanaan pajak sebagai bagian dari manajemen pajak. Agresivitas pajak merupakan suatu tindakan untuk mengurangi penghasilan kena pajak baik secara legal maupun illegal guna mengecilkan beban pajaknya. Bagi perusahaan dengan beban pajak yang tinggi akan mengurangi keuntungan yang diperoleh perusahaan. Istilah yang paling banyak digunakan dalam penelitian adalah tax avoidance dan tax evasion (Novitasari, 2017).

\section{Ukuran Dewan Komisaris}

Menurut peraturan OJK No.33/POJK.04/2014 dewan komisaris merupakan organ emiten atau perusahaan publik yang bertugas untuk melakukan pengawasan secara umum dan atau khusus sesuai dengan anggaran dasar serta memberi nasihat kepada direksi. Ukuran dewan komisaris merupakan jumlah anggota dewan komisaris yang berasal dari internal ataupun eksternal perusahaan (Asmoro, 2016).

\section{5}




\section{Gender Diversity pada Dewan}

Menurut Arfken dkk (2004) perbedaan gender di perusahaan dapat menawarkan satu set manfaat sebagai tambahan pengetahuan, ide-ide baru dan wawasan untuk membantu memecahkan masalah, meningkatkan perencanaan strategis, pengetahuan baru atau pendapat dan pengalaman.

\section{Kualitas Auditor Eksternal}

Menurut Dewi dan Jati (2014) kualitas audit merupakan segala kemungkinan yang dapat terjadi saat auditor mengaudit laporan keuangan klien dan menemukan pelanggaran atau kesalahan yang terjadi, dan melaporkannya dalam laporan keuangan auditan. Selain itu, menurut De Angelo (1981) menyatakan bahwa kualitas audit yang dilakukan oleh akuntan publik dapat dilihat dari ukuran KAP yang melakukan audit. Laporan keuangan yang diaudit oleh KAP besar (KAP Big Four) lebih berkualitas dibandingkan dengan KAP kecil (KAP non-Big Four). Hal tersebut karena KAP besar memiliki lebih banyak sumber daya dan lebih banyak klien sehingga mereka tidak tergantung pada satu atau beberapa klien saja, selain itu karena reputasinya yang telah dianggap baik oleh masyarakat menyebabkan mareka akan melakukan audit dengan lebih berhati-hati.

\section{Ukuran Perusahaan}

Ukuran perusahaan adalah suatu pengukuran yang dikelompokkan berdasarkan besar kecilnya perusahaan dan dapat menggambarkan aktivitas serta pendapatan perusahaan (Nugraha dan Wahyu, 2015). Ukuran perusahaan umumnya dibagi dalam tiga kategori, yaitu perusahaan besar (large firm), perusahaan menengah (medium firm), dan perusahaan kecil (small firm).

\section{Leverage}

Menurut Harahap (2013) leverage merupakan rasio yang menggambarkan hubungan antara utang perusahaan terhadap modal, rasio ini dapat melihat seberapa jauh perusahaan dibiayai oleh utang atau pihak luar dengan kemampuan perusahaan yang digambarkan oleh modal.

\section{Pengaruh Ukuran Dewan Komisaris terhadap Agresivitas Pajak}

Dewan komisaris sebagai anggota organisasi perusahaan harus melaksanakan kewajiban mereka berdasarkan kepentingan perusahaan dan pemegang saham. Banyaknya anggota dewan komisaris di suatu perusahaan maka dapat menyulitkan dalam menjalankan peran dan tugas mereka, diantaranya adalah kesulitan dalam berkomunikasi dan mengkoordinir kerja dari masingmasing anggota dewan itu sendiri, kesulitan dalam mengawasi dan mengendalikan tindakan dari manajemen, serta kesulitan dalam mengambil keputusan yang berguna bagi perusahaan. Dewan komisaris memegang peranan penting dalam mengarahkan strategi dan mengawasi jalannya perusahaan serta memastikan bahwa para manajer benar-benar meningkatkan kinerja perusahaan sebagai bagian dari tujuan perusahaan. Ridwan, Zaitul, dan Resty (2015) serta Wulandari dan 
Septiari (2015) menunjukkan bahwa ukuran dewan komisaris berpengaruh negatif terhadap effective tax rate.

$\mathrm{H}_{1}$ : ukuran dewan komisaris berpengaruh negatif terhadap agresivitas pajak.

\section{Pengaruh Gender Diversity pada Dewan terhadap Agresivitas Pajak}

Hamid dkk (2010) menyarankan perlunya untuk mengintegrasikan variabel gender diversity sebagai variabel pemerintahan ketika mempelajari atribut dewan. Dewan yang heterogenitas akan mempersulit proses keputusan pajak. Gender diversity dewan diukur dalam persentase adanya perempuan yang terdapat dalam jajaran dewan (Aliani dan Ali, 2012). Dalam penelitian yang dilakukan oleh Aliani dkk (2011) menemukan bahwa ada pengaruh negatif antara keragaman gender pada dewan direksi dan optimalisasi pajak, yang artinya bahwa adanya perempuan dalam dewan dapat mengurangi adanya tindakan agresivitas pajak karena perempuan memiliki tingkat kepatuhan pajak yang lebih tinggi dibandingkan dengan laki-laki.

$\mathrm{H}_{2}$ : gender diversity pada dewan berpengaruh negatif terhadap agresivitas pajak.

\section{Pengaruh Kualitas Auditor Eksternal terhadap Agresivitas Pajak}

Kualitas audit dapat diproksikan dengan ukuran KAP yang dibedakan dengan KAP big four dan KAP non big four. KAP big four dipersepsikan akan melakukan audit dengan lebih berkualitas dibandingkan dengan KAP non big four. Hal tersebut karena KAP big four memiliki lebih banyak sumber daya dan lebih banyak klien sehingga mereka tidak tergantung pada satu atau beberapa klien saja, selain itu karena reputasinya yang telah dianggap baik oleh masyarakat menyebabkan mareka akan melakukan audit dengan lebih berhati-hati (Cristiani dan Nugrahanti, 2014). Dewi dan Jati (2014) serta Maharani dan Suardana (2014) menemukan bahwa kualitas audit berpengaruh negatif terhadap tax avoidance, yang artinya bahwa kualitas audit yang tinggi dapat mengurangi praktik penghindaran pajak. Perusahaan yang diaudit oleh KAP besar terbukti tidak melakukan penghindaran pajak, karena auditor yang termasuk dalam big four lebih kompeten dan profesional dibandingkan dengan auditor yang termasuk dalam non big four, sehingga ia memiliki pengetahuan yang lebih banyak tentang cara mendeteksi dan memanipulasi laporan keuangan yang mungkin dilakukan oleh perusahaan.

$\mathrm{H}_{3}$ : kualitas auditor eksternal berpengaruh negatif terhadap agresivitas pajak. 

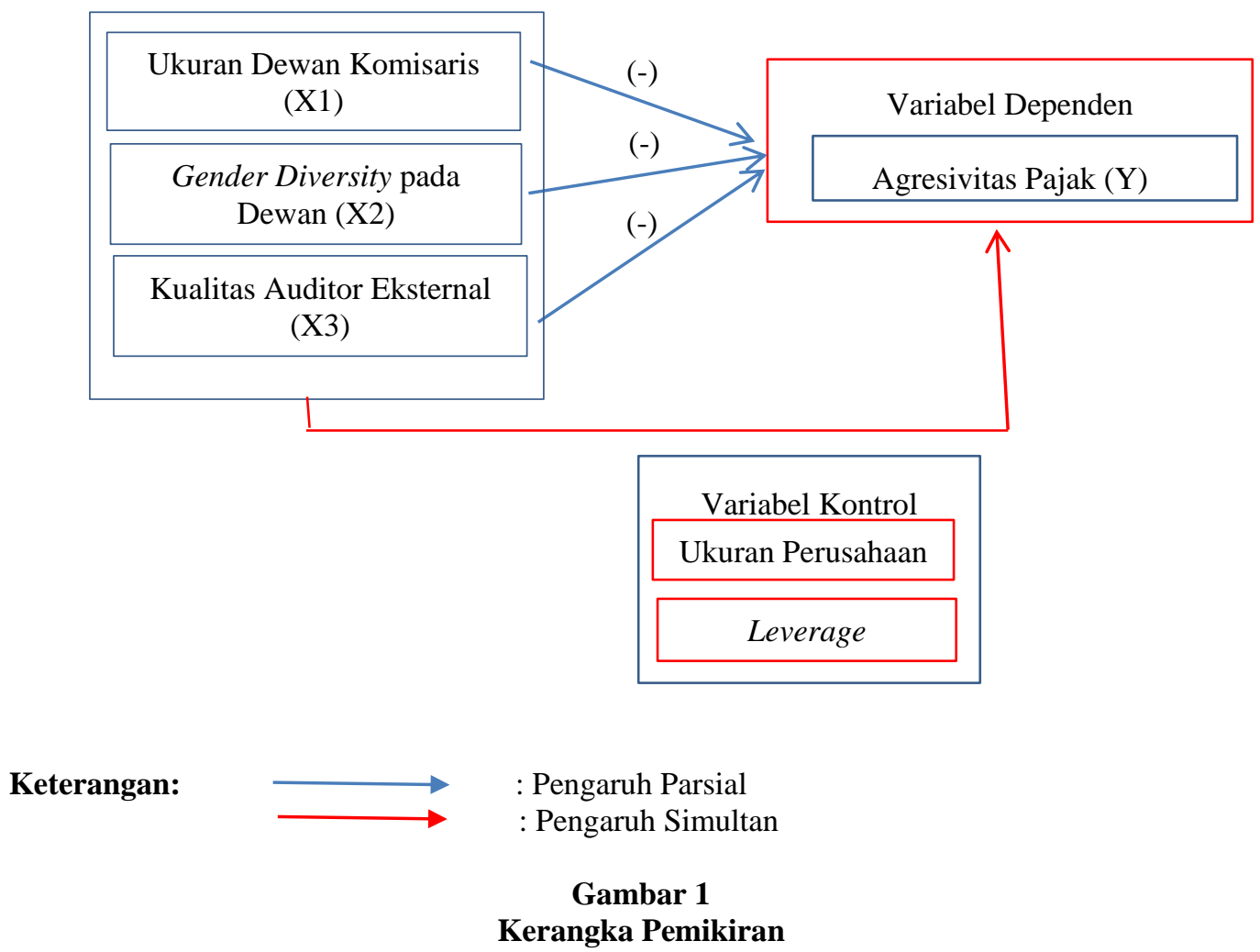

\section{METODE PENELITIAN}

Penelitian ini menggunakan metode kuantitatif. Populasi di dalam penelitian ini adalah perusahaan sektor property dan real estate yang terdaftar di Bursa Efek Indonesia periode 2013-2017. Dalam penelitian ini menggunakan teknik purposive sampling dengan kriteria yaitu perusahaan property dan real estate yang terdaftar di Bursa Efek Indonesia (BEI) periode 2013-2017, perusahaan yang menyediakan laporan keuangan dan tahunan periode 2013-2017 dan tidak didelisting selama periode pengumpulan data, tidak mengalami kerugian fiskal selama periode 2013-2017, perusahaan property dan real estate yang mempublikasikan laporan keuangan secara lengkap selama periode 2013-2017, perusahaan property dan real estate tidak melakukan transaksi akuisisi dan merger selama periode tahun 2013 - 2017. Sehingga didapatkan 140 total sampel penelitian.

\section{Variabel Dependen}

Variabel dependen dalam penelitian ini adalah agresivitas pajak. Dalam penelitian ini agresivitas pajak diproksikan dengan Effective Tax Rate yaitu 
dengan membandingkan beban pajak dengan laba sebelum pajak (Richardson dkk, 2012). Rumus untuk menghitung Effective Tax Rate adalah sebagai berikut:

$$
\mathrm{ETR}=\frac{\text { Beban Pajak }}{\text { Laba Sebelum Pajak }}
$$

\section{Variabel Independen}

\section{a. Ukuran Dewan Komisaris}

Ukuran dewan komisaris merupakan jumlah anggota dewan komisaris yang berasal dari internal ataupun eksternal perusahaan (Asmoro, 2016). Dalam penelitian ini ukuran dewan komisaris diukur dengan jumlah dewan komisaris yang ada dalam perusahaan. Rumus yang digunakan untuk mengukur ukuran dewan komisaris adalah sebagai berikut:

$$
\text { Ukuran Dewan Komisaris = Jumlah Dewan Komisaris }
$$

\section{b. Gender Diversity pada Dewan}

Rovers (2010) meninjau beberapa definisi keragaman. Dia menyimpulkan bahwa gender diversity dalam dewan perusahaan merupakan salah satu dari berbagai aspek keragaman. Dalam penelitian ini rumus untuk mengukur gender diversity pada dewan adalah sebagai berikut:

$$
\text { Gender diversity }=\frac{\text { Jumlah perempuan pada dewan }}{\text { Jumlah dewan direksi + dewan komisaris }}
$$

\section{c. Kualitas Auditor Eksternal}

Kualitas audit dapat diproksikan dengan ukuran KAP yang dibedakan dengan KAP big four dan KAP non big four. Dalam penelitian ini kualitas auditor eksternal diukur dengan menggunakan dummy variable yaitu: bernilai 1 jika perusahaan menggunakan jasa auditor eksternal big four yaitu EY, Deloitte, KPMG, PWC; bernilai 0 jika perusahaan menggunakan auditor eksternal non big four.

\section{Variabel Kontrol}

a. Ukuran Perusahaan

Ukuran perusahaan menunjukan besar kecil nya perusahaan yang diukur dengan rumus:

$$
S I Z E=\operatorname{Ln}(\text { total aktiva })
$$

\section{b. Leverage}

Menurut Harahap (2013) leverage merupakan rasio yang menggambarkan hubungan antara utang perusahaan terhadap modal, rasio ini dapat melihat seberapa jauh perusahaan dibiayai oleh utang atau pihak luar dengan kemampuan perusahaan yang digambarkan oleh modal. Dalam penelitian ini leverage diukur dengan menggunakan rumus:

$$
\text { DER }=\frac{\text { Total Utang }}{\text { Total Equity }} \times 100 \%
$$




\section{Metode Analisis Data}

Teknik analisis data yang digunakan dalam penelitian ini adalah analisis regresi data panel yang memiliki persamaan sebagai berikut:

$$
\mathrm{Y}_{\mathrm{it}}=\propto+\beta 1 \mathrm{X} 1_{\mathrm{it}}+\beta 2 \mathrm{X} 2_{\mathrm{it}}+\beta 3 \mathrm{X} 3_{\mathrm{it}}+\beta 4 \mathrm{X} 4_{\mathrm{it}}+\beta 5 \mathrm{X} 5_{\mathrm{it}}+\varepsilon
$$

Keterangan:

$\mathrm{Y}_{\text {it }} \quad=$ Agresivitas pajak pada perusahaan i tahun ke- $\mathrm{t}$

$\mathrm{X}_{1 \mathrm{it}} \quad=$ Ukuran dewan komisaris pada perusahaan i tahun ke- $\mathrm{t}$

$\mathrm{X} 2_{\mathrm{it}} \quad=$ Gender diversity pada dewan perusahaan i tahun ke- $\mathrm{t}$

$\mathrm{X} 3_{\text {it }} \quad=$ Kualitas auditor eksternal pada perusahaan i tahun ke-t

$\mathrm{X} 4_{\text {it }} \quad=$ Ukuran perusahaan pada perusahaan $\mathrm{i}$ tahun ke- $\mathrm{t}$

$\mathrm{X} 5_{\mathrm{it}} \quad=$ Leverage pada perusahaan i tahun ke- $\mathrm{t}$

$\propto \quad=$ Konstanta

$\beta 1, \ldots ., \beta 5=$ Koefisien regresi masing-masing variabel

$\varepsilon \quad=$ Error term

\section{HASIL PENGUJIAN HIPOTESIS} Analisis Statistik Deskriptif

Tabel 1. Descriptive Statistics

\begin{tabular}{|l|r|r|r|r|r|r|}
\hline Keterangan & $\begin{array}{c}\text { Agresivitas } \\
\text { Pajak }\end{array}$ & $\begin{array}{c}\text { Ukuran } \\
\text { Dewan } \\
\text { Komisaris }\end{array}$ & $\begin{array}{c}\text { Gender } \\
\text { Diversity }\end{array}$ & $\begin{array}{c}\text { Kualitas } \\
\text { Auditor } \\
\text { Eksternal }\end{array}$ & $\begin{array}{c}\text { Ukuran } \\
\text { Perusahaan }\end{array}$ & Leverage \\
\hline Mean & 0,11607 & 5,03571 & 0,15699 & 0,28571 & 28,32150 & 77,88298 \\
\hline Maksimum & 0,75218 & 22 & 0,50000 & 1 & 31,67007 & 367,36025 \\
\hline Minimum & 0,00006 & 2 & 0 & 0 & 21,76513 & 7,37858 \\
\hline Std. Dev. & 0,13884 & 3,51443 & 0,11737 & 0,45338 & 2,53955 & 52,69153 \\
\hline N & 140 & 140 & 140 & 140 & 140 & 140 \\
\hline
\end{tabular}

Sumber: data yang diolah Eviews, 2018

Berdasarkan Tabel 1 dapat diketahui nilai minimum, nilai maksimum, ratarata (mean), dan standar deviasi untuk masing-masing variabel. Jumlah keseluruhan data $(\mathrm{N})$ sebanyak 140.

\section{Analisis Regresi Data Panel}

Berdasarkan pengujian model yang telah dilakukan sebelumnya, maka model yang sesuai untuk penelitian ini adalah Fixed Effect. Hasil uji model Fixed effect yang diolah menggunakan software Eviews tersaji dalam tabel 2.

\section{Tabel 2 Hasil Uji Signifikansi Model Fixed Effect}

Dependent Variable: Y

Method: Panel EGLS (Cross-section weights)

Date: 12/20/18 Time: 23:16

Sample: 20132017

Periods included: 5

Cross-sections included: 28

Total panel (balanced) observations: 140

Linear estimation after one-step weighting matrix 


\begin{tabular}{crrrr}
\hline \hline Variable & Coefficient & Std. Error & t-Statistic & Prob. \\
\hline \hline C & 2.483734 & 2.385097 & 1.041355 & 0.3001 \\
X1 & 0.005117 & 0.003930 & 1.301789 & 0.1958 \\
X2 & -0.309122 & 0.061683 & -5.011471 & 0.0000 \\
X3 & -2.162208 & 8.417547 & -0.256869 & 0.7978 \\
Size & -0.062787 & 0.014553 & -4.314233 & 0.0000 \\
Leverage & 0.000681 & 0.000289 & 2.360032 & 0.0201 \\
\hline \hline
\end{tabular}

Effects Specification

\begin{tabular}{llll}
\hline \hline \multicolumn{4}{l}{ Cross-section fixed (dummy variables) } \\
\hline \hline
\end{tabular}

Sumber: data yang telah diolah dengan Eviews, 2018

Berdasarkan Tabel 2 persamaan regresi data panel dapat dirumuskan:

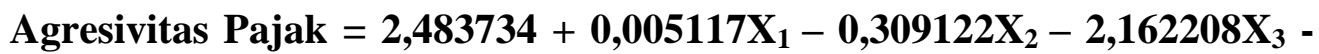
$0,062787 \mathrm{X}_{4}+0,000681 \mathrm{X}_{5}+\varepsilon$

Keterangan: X1 : Ukuran dewan komisaris

$\mathrm{X} 2$ : Gender diversity pada dewan

$\mathrm{X} 3$ : Kualitas auditor eksternal

$\mathrm{X} 4$ : Ukuran perusahaan

$\mathrm{X} 5$ : Leverage

$\varepsilon \quad:$ Errorterm

Persamaan regresi data panel tersebut dapat diartikan sebagai berikut:

1. Nilai konstanta sebesar 2,483734 artinya jika variabel independen ukuran dewan komisaris, gender diversity pada dewan, dan kualitas auditor eksternal benilai 0 , maka besarnya agresivitas pajak yang dilakukan nilainya sebesar 2,483734 satuan.

2. Koefisien regresi ukuran dewan komisaris $\left(\mathrm{X}_{1}\right)$ sebesar 0,005117 . Nilai koefisien regresi variabel ukuran dewan komisaris bernilai positif. Hal ini berarti jika ukuran dewan komisaris meningkat sebesar 1 satuan dan variabel lainnya tetap maka agresivitas pajak akan bertambah sebesar 0,005117 satuan.

3. Koefisien regresi gender diversity pada dewan $\left(\mathrm{X}_{2}\right)$ sebesar $-0,309122$ menunjukkan arah negatif yang berarti jika jumlah perempuan pada gender 
diversity pada dewan meningkat dan variabel lainnya tetap maka agresivitas pajak akan berkurang sebesar 0,309122 satuan.

4. Koefisien regresi kualitas auditor eksternal $\left(\mathrm{X}_{3}\right)$ sebesar -2,162208 menunjukkan arah negatif yang berarti jika perusahaan menggunakan jasa auditor eksternal big four dan variabel lainnya tetap maka agresivitas pajak akan berkurang sebesar 2,162208 satuan.

5. Koefisien regresi ukuran perusahaan $\left(X_{4}\right)$ sebesar $-0,062787$ menunjukkan arah negatif yang berarti jika ukuran perusahaan meningkat sebesar 1 satuan dan variabel lainnya tetap maka agresivitas pajak akan berkurang sebesar 0,062787 satuan.

6. Koefisien regresi leverage $\left(\mathrm{X}_{5}\right)$ sebesar 0,000681 menunjukkan arah positif yang berarti jika nilai leverage meningkat sebesar 1 satuan dan variabel lainnya tetap maka agresivitas pajak akan bertambah sebesar 0,000681 satuan.

\section{Koefisien Determnasi $\left(\mathbf{R}^{2}\right)$}

Berdasarkan hasil uji signifikansi model fixed effect pada Tabel 2 dapat dilihat bahwa nilai Adjusted R-square sebesar 0,578557 atau 57,8557\%. Dengan demikian, maka dapat disimpulkan bahwa variabel independen ukuran dewan komisaris, gender diversity pada dewan, dan kualitas auditor eksternal dapat menjelaskan agresivitas pajak yang diproksikan dengan Effective Tax Rate (ETR) pada perusahaan property dan real estate periode 2013-2017 sebesar 57,8557\%; sedangkan sisanya $42,1443 \%$ dijelaskan oleh variabel lain diluar penelitian.

\section{Uji Signifikansi Simultan}

Berdasarkan hasil uji signifikansi model fixed effect pada Tabel 2 dapat ilihat bahwa nilai $\operatorname{Prob}(F$-statistic $)$ sebesar $0,000000<0,05$, maka dapat dikatakan ukuran dewan komisaris $\left(\mathrm{X}_{1}\right)$, gender diversity pada dewan $\left(\mathrm{X}_{2}\right)$, kualitas auditor eksternal $\left(\mathrm{X}_{3}\right)$, ukuran perusahaan $\left(\mathrm{X}_{4}\right)$, leverage $\left(\mathrm{X}_{5}\right)$ secara simultan berpengaruh terhadap agresivitas pajak (Y).

\section{Uji Signifikansi Parsial}

Pengujian parsial dilakukan untuk menentukan signifikan atau tidak signifikan masing-masing nilai koefisien regresi secara sendiri-sendiri terhadap variabel terikat. Berdasarkan Tabel 2 dapat disimpulkan sebagai berikut:

1. Nilai probabilitas variabel independen ukuran dewan komisaris sebesar 0,1958. Nilai tersebut menunjukkan bahwa 0,1958 > 0,05, maka dapat disimpulkan bahwa $\mathrm{H}_{01}$ diterima dan $\mathrm{H}_{\mathrm{a} 1}$ ditolak sehingga ukuran dewan komisaris tidak berpengaruh negatif terhadap agresivitas pajak.

2. Nilai probabilitas variabel independen gender diversity pada dewan sebesar 0,0000. Nilai tersebut menunjukkan bahwa $0,0000<0,05$, maka dapat disimpulkan bahwa $\mathrm{H}_{02}$ ditolak dan $\mathrm{H}_{\mathrm{a} 2}$ diterima sehingga gender diversity pada dewan berpengaruh negatif terhadap agresivitas pajak.

3. Nilai probabilitas variabel independen kualitas auditor eksternal sebesar 0,7978. Nilai tersebut menunjukkan bahwa $0,7978>0,05$, maka dapat 
disimpulkan bahwa $\mathrm{H}_{03}$ diterima dan $\mathrm{H}_{\mathrm{a} 3}$ ditolak sehingga kualitas auditor eksternal tidak berpengaruh negatif terhadap agresivitas pajak.

\section{Pengaruh Ukuran Dewan Komisaris terhadap Agresivitas Pajak}

Hasil pengujian secara parsial atau uji t pada Tabel 2 menunjukkan bahwa ukuran dewan komisaris memiliki nilai probabilitas 0,1958, di mana nilai tersebut lebih besar dari taraf signifikansi yaitu 0,05 sehingga dapat diambil keputusan bahwa $\mathrm{H}_{01}$ diterima dan $\mathrm{H}_{\mathrm{a} 1}$ ditolak yang berarti bahwa secara parsial ukuran dewan komisaris tidak berpengaruh negatif terhadap agresivitas pajak. Hal tersebut berarti bahwa ukuran dewan komisaris yang kecil atau jumlah dewan komisaris yang sedikit tidak dapat mengurangi adanya tindakan agresivitas pajak.

Berdasarkan Peraturan Otoritas Jasa Keuangan Nomor 33/POJK.04/2014 Pasal 20 ayat (1) yang menyatakan bahwa Dewan Komisaris paling kurang terdiri dari 2 (dua) orang anggota Dewan Komisaris. Berdasarkan hasil analisis deskriptif pada Tabel 1 ukuran dewan komisaris memiliki nilai mean sebesar 5,03571, dari data sampel yang diteliti oleh peneliti menunjukkan bahwa sebanyak 106 sampel dari perusahaan sektor property dan real estate yang terdaftar di Bursa Efek Indnesia (BEI) periode 2013-2017 memiliki jumlah dewan komisaris dibawah nilai mean. Sedangkan 34 sampel dari perusahaan sektor property dan real estate yang terdaftar di Bursa Efek Indnesia (BEI) periode 2013-2017 memiliki jumlah dewan komisaris diatas nilai mean. Hal tersebut sudah sesuai dengan Peraturan Otoritas Jasa Keuangan Nomor 33/POJK.04/2014 Pasal 20 ayat (1). Namun ukuran dewan komisaris yang kecil atau jumlah dewan komisaris yang sedikit tidak dapat mengurangi adanya tindakan agresivitas pajak pada perusahaan sektor property dan real estate yang terdaftar di Bursa Efek Indonesia (BEI) periode 2013-2017. Semakin kecil ukuran dewan komisaris belum tentu dapat mampu meningkatkan kepatuhan perusahaan untuk tidak melakukan tindakan agresivitas pajak. Hasil penelitian ini tidak sesuai dengan hipotesis yang dikembangkan oleh peneliti yang menyatakan bahwa ukuran dewan komisaris berpengaruh negatif terhadap agresivitas pajak. Hal ini sejalan Aliani dan Ali (2012) yang menemukan adanya non-signifikansi antara ukuran dewan komisaris dan agresivitas pajak.

\section{Pengaruh Gender Diversity pada Dewan terhadap Pengaruh Agresivitas Pajak}

Hasil pengujian secara parsial atau uji t pada Tabel 2 menunjukkan bahwa gender diversity pada dewan memiliki nilai probabilitas 0,0000 , di mana nilai tersebut lebih kecil dari taraf signifikansi yaitu 0,05 sehingga dapat diambil keputusan bahwa $\mathrm{H}_{02}$ ditolak dan $\mathrm{H}_{22}$ diterima yang berarti bahwa secara parsial gender diversity pada dewan berpengaruh negatif terhadap agresivitas pajak. Hal tersebut berarti bahwa adanya perempuan dalam dewan dapat mengurangi adanya tindakan agresivitas pajak karena perempuan memiliki tingkat kepatuhan pajak yang lebih tinggi dibandingkan dengan laki-laki.

Gender diversity pada dewan memiliki nilai koefisien regresi sebesar 0,309122 menunjukkan arah negatif yang berarti jika nilai agresivitas pajak meningkat sebesar 1 satuan dan variabel lainnya tetap maka agresivitas pajak akan berkurang sebesar 0,309122 satuan. Nilai koefisien regresi variabel bernilai

\section{3}

Ambarsari $^{1}$, Pratomo $^{2}$, Kurnia $^{3}$ 
negatif yang berarti gender diversity pada dewan dapat mengurangi adanya tindakan agresivitas pajak.

Berdasarkan hasil analisis deskriptif pada Tabel 1 gender diversity pada dewan memiliki nilai mean sebesar 0,15699, dari data sampel yang diteliti oleh peneliti bahwa sebanyak 112 sampel atau setara dengan 80\% sampel pada perusahaan sektor property dan real estate yang terdaftar di Bursa Efek Indnesia (BEI) periode 2013-2017 terdapat dewan yang berjenis kelamin perempuan dalam jajaran dewan, hanya 28 sampel atau setara dengan $20 \%$ sampel yang tidak terdapat dewan yang berjenis kelamin perempuan. Hal tersebut berarti mampu membuktikan bahwa perempuan dapat mencegah terjadinya tindakan agresivitas pajak pada perusahaan sektor property dan real estate yang terdaftar di Bursa Efek Indonesia (BEI) periode 2013-2017. Hasil penelitian ini sesuai dengan hipotesis yang dikembangkan oleh peneliti yang menyatakan bahwa gender diversity pada dewan berpengaruh negatif terhadap agresivitas pajak. Hal ini sejalan dengan Aliani et al. (2011) menemukan bahwa ada pengaruh negatif antara keragaman gender pada dewan direksi dan optimalisasi pajak.

\section{Pengaruh Kualitas Auditor Eksternal terhadap Agresivitas Pajak}

Hasil pengujian secara parsial atau uji t pada Tabel 2 menunjukkan bahwa kualitas auditor eksternal memiliki nilai probabilitas 0,7978 , di mana nilai tersebut lebih besar dari taraf signifikansi yaitu 0,05 sehingga dapat diambil keputusan bahwa $\mathrm{H}_{03}$ diterima dan $\mathrm{H}_{\mathrm{a}}$ ditolak yang berarti bahwa secara parsial kualitas auditor eksernal tidak berpengaruh negatif terhadap agresivitas pajak. Hal tersebut berarti bahwa perusahaan yang diaudit oleh KAP besar atau KAP big four yaitu EY, KPMG, Delloite, PWC belum terbukti dapat mengurangi tidakan agresivitas pajak.

Kualitas auditor eksternal memiliki nilai koefisien regresi sebesar -2,162208 menunjukkan arah negatif yang berarti jika nilai agresivitas pajak meningkat sebesar 1 satuan dan variabel lainnya tetap maka agresivitas pajak akan berkurang sebesar 2,162208 satuan. Nilai koefisien regresi variabel bernilai negatif yang berarti kualitas auditor eksternal dapat mengurangi adanya tindakan agresivitas pajak. Hal tersebut dapat diartikan bahwa KAP non big four juga mampu mengurangi adanya tindakan agresivitas pajak.

Berdasarkan hasil analisis deskriptif pada Tabel 1 kualitas audior eksternal memiliki nilai mean sebesar 0,28571, dari data sampel yang diteliti oleh peneliti menunjukkan bahwa sebanyak 40 sampel dalam perusahaan sektor property dan real estate yang terdaftar di Bursa Efek Indonesia (BEI) periode 2013-2017 yang menggunakan auditor dari KAP big four dan sebanyak 100 sampel menggunakan auditor dari KAP non big four. Hasil penelitian ini tidak sesuai dengan hipotesis yang dikembangkan oleh penulis yang menyatakan bahwa kualitas auditor eksternal berpengaruh negatif terhadap agresivitas pajak. Hal ini sejalan Kusuma dan Firmansyah (2018) yang menyatakan bahwa kualitas auditor eksternal big four tidak berpengaruh terhadap agresivitas pajak.

\section{4}




\section{KESIMPULAN, KETERBATASAN DAN SARAN}

Penelitian ini betujuan untuk mengetahui pengaruh ukuran dewan komisaris, gender diversity pada dewan, dan kualitas auditor eksternal terhadap agresivitas pajak pada perusahaan sektor property dan real estate yang terdaftar di Bursa Efek Indonesia (BEI) periode 2013-2017. Jumlah sampel dalam penelitian ini yaitu terdapat 28 perusahaan dalam kurun waktu 5 (lima) tahun sehingga diperoleh sebanyak 140 sampel penelitian. Berdasarkan pengujian hipotesis, dapat disimpulkan:

a. Ukuran dewan komisaris tidak berpengaruh negatif terhadap agresivitas pajak;

b. Gender diversity pada dewan berpengaruh negatif terhadap agresivitas pajak;

c. Kualitas audior eksternal tidak berpengaruh negatif terhadap agresivitas pajak.

Penelitian ini dilakukan dengan berbagai keterbatasan yang mempengaruhi hasil penelitian. Pertama, hasil penelitian dari ukuran dewan komisaris tidak terdapat pengaruh terhadap agresivitas pajak hal tersebut disebabkan karena jumlah dewan komisaris dalam perusahaan property dan real estate memiliki nilai mean sebesar 5,03571, sehingga dapat dinyatakan bahwa ukuran dewan komisarisnya besar. Kedua, dapat diketahui ternyata audit yang dilakukan oleh KAP non Big Four juga dapat dipercaya hasil auditnya karena KAP non Big Four juga mampu mencegah adanya tindakan agresivitas pajak.

Berdasarkan hasil penelitian yang telah dilakukan peneliti memberikan saran untuk peneliti selanjutnya yang akan menggunakan variabel kualitas auditor eksternal agar memperhatikan KAP big four maupun KAP non big four. Karena hal tersebut akan mempengaruhi hasil penelitian. Dalam penelitian ini KAP non big four juga memiliki pengaruh untuk mencegah adanya tindakan agresivitas pajak.

Bagi perusahaan, untuk memperhatikan lagi adanya dewan yang berjenis kelamin perempuan dalam jajaran dewan komisaris dan dewan direksi karena hal tersebut dapat mengurangi adanya tindakan agresivitas pajak. Hal tersebut terjadi karena perempuan memiliki tingkat kepatuhan pajak yang lebih tinggi dibandingkan dengan laki-laki.

Selain itu perusahaan juga harus memperhatikan kualitas auditor eksternal karena dalam penelitian ini KAP non big four juga dapat mengurangi adanya tindakan agresivitas pajak pada perusahaan sektor property dan real estate yang terdaftar di BEI periode 2013-2017. Bagi investor, gender diversity pada dewan dapat dijadikan pertimbangan oleh investor dalam melakukan pengambilan keputusan untuk berinvestasi karena banyak perusahaan sektor property dan real estate yang terdaftar di Bursa Efek Indonesia periode 2013-2017 yang memiliki anggota dewan yang berjenis kelamin perempuan dalam jajaran dewan komisaris dan dewan direksi. Hal tersebut dapat mengurangi adanya tidakan agresivitas pajak sehingga tingkat risiko yang dimiliki perusahaan terkait dengan bidang pepajakan semakin kecil. Selain itu perusahaan sektor property dan real estate yang diaudit oleh KAP non big four juga mampu mencegah adanya tindakan agresivitas pajak. Bagi Direktorat Jenderal Pajak, untuk meningkatkan lagi

\section{5}

Ambarsari $^{1}$, Pratomo $^{2}$, Kurnia ${ }^{3}$ 
kebijakan-kebijakan terhadap perusahaan sehingga tindakan agresivitas pajak dapat dikurangi dan perusahaan menjadi semakin patuh dalam membayarkan pajaknya. Sehingga, pemasukan pemerintah dari bidang perpajakan menjadi semakin meningkat.

\section{DAFTAR PUSTAKA}

Aliani, K., \& Mohamed Ali, Z. (2012). Demographic Diversity in the board and corporate tax planning in American firms. Business Management and Strategy, Vol. 3, No. 1, ISSN: 2157-6068.

Aliani, K., M. Hamid, I., \& Zarai, M. A. (2011). Diversity in kind in the board of directors and tax optimization: validation in the Tunisian context. Journal of Management and Global Business Research, 11, 41-50.

Arfken, D, Bellar, S, dan Helms, M. 2004. The Ultimate Glass Ceiling Revisited:

The Presence of Women on Corporate Boards. Journal of Business ethics, 50, 177-186.

Asmoro, A. (2016). Analisis Determinan pengungkapan Enterprise Risk Management (Studi pada Perusahaan yang terdaftar dalam Indeks IDX30 di BEI periode 2012-2014). e-Proceending of Management, Vol.3, No.3, ISSN: 2355-9357.

Boussaidi, A., \& Hamed, M. S. (2015). The Impact of Governance Mechanism on Tax Aggressiveness: Empirical Evidence from Tunisian Context. Journal of Asian Bussiness Strategy, Vol. 5, Issue 1, ISSN (E): 2225-4226.

Cristiani, I., \& Nugrahanti, Y. W. (2014). Pengaruh Kualitas Audit terhadap Manajemen Laba. Jurnal Akuntansi dan Keuangan, Vol. 16, No. 1, ISSN: 2338-8137

DeAngelo, L.E. (1981). Auditor Size and Audit Quality. Journal of Accounting and Economics, Vol.3, 183-199.

Detik Finance. (2013, 13 Agustus). Ditjen Pajak Sulit Kejar Penghindaran Pajak Transaksi Properti Perorangan. [online]. Tersedia: https://finance.detik.com/properti/d-2328527/ditjen-pajak-sulit-kejarpenghindar-pajak-transaksi-properti-perorangan [10 September 2018]

Dewi, K., \& Jati, I. (2014). Pengaruh Karakter Eksekutif, Karateristik Perusahaan, dan Corporate Governance pada Tax Avoidance di Bursa Efek Indonesia. EJurnal Akuntansi, Vol. 6, No. 2, ISSN: 2302-8556.

Harahap, S. S. (2013). Analisis Kritis Atas Laporan Keuangan (Edisi 11). Jakarta: Rajawali Pers

Kamila, Putri Almainda. (2014). Analisis Hubungan Agresivitas Pelaporan Keuangan dan Agresivitas Pajak. E-Jurnal Fakultas Ekonomi dan Bisnis Universitas Indonesia, ISSN 1410-8623.

Kusuma, C., \& Firmansyah, A. (2018). Manajemen Laba, Corporate Governance, Kualitas Auditor Eksternal, dan Agresivitas Pajak. Jurnal Tekun, Vol. 8, No. 1, e-ISSN: 2622-1470.

Luckerath, R. (2010). Women on board and firm performance. SSRN Electronic Journal, Vol. 17, Issue. 2.

Maharani, I., \& Alit Suardana, K. (2014). Pengaruh Corporate Governance, Profitabilitas, Karakteristik Eksekutif pada Tax Avoidance Perusahaan 
Manufaktur. E-Jurnal Akuntansi Universitas Udayana, Vol. 9, No. 2, 525539, ISSN: 2302-8556.

M. Hamid, I., \& Hachana, R. (2010). Diversite en genre au top management, Divulgation des valeurs feminines et performance, l'exception Tunisienne. Global Journal of Strategies and Governance, 1(2), 3-23.

Novitasari, S. (2017). Pengaruh Manajemen Laba, Corporate Governance, dan Intensitas Modal terhadap Agresivitas Pajak Perusahaan (Studi Empiris pada Perusahaan Properti dan Real Estate yang Terdaftar di BEI Periode Tahun 2010-2014). Jurnal Ekonomi Universitas Riau, Vol. 4, No. 1, ISSN: 19011914.

Nugraha, N. B., \& Wahyu, M. (2015). Pengaruh Corporate Social Responsibility, Ukuran Perusahaan, Profitabilitas, Leverage dan Capital Intensity terhadap Agresivitas Pajak (Studi Empiris pada Perusahaan Non-Keuangan yang terdaftar di BEI Tahun 2012-2013). Diponegoro Journal of Accounting, Vol.4, No. 4, ISSN (Online): 2337-3806, Hal. 1-14.

Otoritas Jasa Keuangan. (2018). Peraturan Otoritas Jasa Keuangan No.33/POJK.04/2014 [online]. Tersedia: http://www.ojk.go.id/ [28 Oktober 2018]

Richardon, G dan Roman, L. 2011. The Effect of Board of Directors Composition

on Corporatetax Aggressiveness. Journal of Accounting and Public policy, Vol. 30, No. 50-70.

Richardson, G., Taylor, G., \& Lanis, R. (2013). The Impact of Risk Management and Audit Characteristics on Corporate Tax Aggresiveness: An Empirical Analysis. Journal of Accounting and Public Policy, Vol. 32, 68-88.

Ridwan, Y., Zaitul, \& Yulistia, R. (2015). Pengaruh Gender Diversity pada Dewan Komisaris, Dewan Komisaris Independen, Ukuran Dewan Komisaris Terhadap Perencanaan Pajak. E-Journal Bung Hatta, Vol. 6, No. 1.

Santoso, I., \& Rahayu, N. (2013). Corporate Tax Management. Ortax (IN).

Tambunan, Edi Sihar. (2015, 8 Mei). Problematika Pajak di Balik Maraknya Bisnis Properti. [online]. Tersedia: https://majalahpajak.net/ [9 September 2018]

Wahyudi. (2012). Perspektif Pajak sebagai Sarana Pendukung Pembangunan. [online]. Tersedia: https://eddiwahyudi.com [9 September 2018]

Wulandari, M., \& Septiari, D. (2015). Effective Tax Rate: Efek dari Corporate Governance. Jurnal Akuntansi, Ekonomi, dan Manajemen Bisnis, Vol. 3, No. 2, ISSN: $2337-2887$ 